\title{
UJI SOMATIK INKOMPATIBILITAS Ganoderma philippii UNTUK MENGETAHUI POLA SEBARAN PENYAKIT BUSUK AKAR PADA TANAMAN Acacia mangium
}

Somatic Incompatibility Test to Reveal Disease Spread of Ganoderma philippii in

Acacia mangium Plantation

\author{
Desy Puspitasari dan Anto Rimbawanto \\ Balai Besar Penelitian Bioteknologi dan Pemuliaan Tanaman Hutan \\ Jl. Palagan Tentara Pelajar Km. 15, Purwobinangun, Pakem, Sleman, Yogyakarta 55582 \\ Telp. (0274) 895954, 896080, Fax. (0274) 896080
}

\begin{abstract}
Ganoderma philippii is a fungi causing root rot disease that have spread widely in Acacia mangium plantation. Study on mode of disease spreading is necessary to develop ways of controlling the spread of the disease. Somatic incompatibility test was carried out using fungal cultures that has been identified as G. philippii from two sites of different rotation. Each location showing different type of incompatibility. Compatible reaction was observed at Logas of first rotation indicating that the isolates are not genotypically distinct and may come from closely related clones. At this site the spread of root rot occurred by root to root contact. Incompatible reaction was observed at Deras of second rotation indicating that $\mathrm{G}$. philippii isolate are genotypically distinct individuals and of different clones, eventhough they share same morphological characters. Genetic diversity found in $\mathrm{G}$. philippii suggested that sexual reproduction of basidiocarps is an important factor and is strongly implicated as one of the main modes of dispersal as well as root to root contact.
\end{abstract}

Key Words : Ganoderma philippii, somatic incompatibility, root rot

\begin{abstract}
ABSTRAK
Jamur Ganoderma philippii penyebab penyakit busuk akar telah menyebar luas di beberapa areal HTI Acacia mangium di Indonesia. Untuk mengendalikan meluasnya penyakit busuk akar perlu diketahui pola persebaran penyakit busuk tersebut. Tes somatik inkompatibilitas merupakan salah satu cara untuk memahami pola persebaran penyakit agar dapat dikembangkan cara-cara untuk mencegah meluasnya serangan penyakit. Tes somatik inkompatibilitas dilakukan pada koleksi isolat jamur yang telah diidentifikasi sebagai jamur Ganoderma philippii dari dua lokasi yang berbeda rotasi tanam. Pada tiap rotasi tanam menunjukkan adanya perbedaan tipe inkompatibilitas. Reaksi kompatibel ditemukan di Logas rotasi pertama yang mengindikasikan tidak adanya keragaman genetik dan mempunyai hubungan klon yang sama. Pola persebaran pada lokasi Logas diyakini terjadi melalui kontak akar. Reaksi inkompatibel ditemukan di Deras rotasi kedua, yang mengindikasikan bahwa
\end{abstract}


isolat jamur Ganoderma philippii mempunyai genotip yang berbeda dan tidak berasal dari satu klon yang sama, meskipun mempunyai kesamaan secara morfologi. Adanya keragaman genetik pada Ganoderma philippii menunjukkan bahwa pola persebaran penyakit busuk akar terjadi melalui gabungan antara persebaran spora dan kontak akar.

\section{Kata Kunci : Ganoderma philippii, somatik inkompatibilitas, penyakit busuk akar}

\section{PENDAHULUAN}

Penanaman hutan industri dengan jenis dan umur yang seragam secara monokultur memperbesar resiko berkembangnya penyakit secara pesat dan membuat pohon menjadi lebih peka terhadap berbagai macam penyakit yang muncul. Golani (2006) mencontohkan penyakit busuk akar (root rot) sebagai salah satu penyakit yang epidemik pada tanaman monokultur yang seragam kondisinya. Acacia mangium Wild. merupakan tanaman yang rentan terhadap serangan root rot yang dapat menyebabkan berkurangnya kualitas dan kuantitas hasil kayu yang diproduksi (Old et al.,2000; Irianto et al., 2006). Cara pengendalian (pengontrolan) penyakit busuk akar masih sulit dilakukan karena jamur penyebab penyakit busuk akar merupakan jenis jamur soil-borne pathogen yang dapat bertahan hidup pada bahan berkayu di dalam tanah (Old et al., 2000).

Ganoderma philippii merupakan jamur penyebab busuk akar merah dari golongan Basidiomycetes (Hood, 2006) yang banyak ditemukan pada tanaman Acacia di Indonesia (Lee, 2000; Glen et al., 2006; Glen et al., 2009). G. philippii ditemukan tidak hanya menyerang pada tanaman Acacia tetapi juga pada perke- bunan teh dan tanaman Karet (Hevea brasiliensis) sebagai patogen sekunder yang mempunyai kesamaan sub-cluster $\mathrm{C}$ berdasarkan hasil dendrogram pada UPGMA cluster analysis of RAPD dengan nilai kesamaan genetik $70 \%$ untuk isolat G. philippii dari perkebunan teh dan $100 \%$ untuk isolat $G$. philippii dari tanaman karet dengan isolat referensi $G$. philippii FP589 (Latiffah et al., 2009). Ganoderma philippii yang ditemukan pada tanaman Acacia mangium di Sumatera Selatan (E7108), Kalimantan Timur (E7379), Riau (E7098) dan Malaysia (E7425) mempunyai urutan DNA yang identik satu sama lain dengan tingkat kesamaan genetik $97 \%$ dan mempunyai kemiripan dengan urutan DNA $G$. philippii yang berasal dari tanaman karet (Hevea brasiliensis) FP589 (Glen et al., 2009).

Somatik inkompatibilitas dalam Basidiomycetes adalah penolakan miselia yang berlainan genetik yang berfungsi untuk menjaga agar dalam suatu individu tidak terjadi perubahan genetik. Somatik inkompatibilitas mengatur penolakan dan pengakuan alel-alel atau gen-gen yang sesuai dan tidak sesuai yang mengikuti pembentukan sel tubuh dalam sebuah grup organisme. Somatik inkompatibilitas sangat 
berperan penting dalam konsep individual pada jamur (Worall, 1997).

Fries (1987) menjelaskan bahwa studi tentang somatik inkompatibilitas dapat digunakan untuk mengetahui apakah setiap pohon yang terserang jamur berasal dari klon jamur yang sama atau berbeda yang nantinya dapat digunakan untuk menganalisis populasi dan persebaran jamur di lapangan. Mounce (1929) dalam Worall (1997) menjelaskan tentang konsep somatik inkompatibilitas dengan menggunakan isolat Fomitopsis pinicola. Bentuk reaksi dari penghambatan antara dua isolat yang dipasangkan bervariasi mulai dari adanya zona jarang antara dua miselia yang dipasangkan, adanya batas pada salah satu atau kedua miselia, terbentuknya garis demarkasi yang berwarna gelap karena pembentukan pigmentasi (El Karkouri et al., 1996; Miller et al., 1999; Suwandi et al., 2004; Guler, 2008) dan pembentukan dinding sclerotia di antara miselia yang merupakan penggumpalan hifa. Fenomena ini hanya terjadi pada miselium atau isolat yang mempunyai keragaman genetik (heterokaryotik) atau miselium dikaryotik yang tidak berasal dari satu klon genetik. Pada isolat yang dipasangkan dengan dirinya sendiri atau self-pairings yang menunjukkan tidak adanya keragaman genetik, miselium jamur akan menggabung dan tumbuh bersama membentuk koloni tunggal. Studi tentang somatik inkompatibilitas ini dapat digunakan untuk mengetahui distribusi genotip pada suatu populasi.

Tulisan ini memaparkan tentang studi somatik inkompatibilitas dari jamur Ganoderma philippii untuk mengetahui tipe persebaran jamur penyebab busuk akar pada Acacia mangium dan mengetahui distribusi keragaman genetik dalam suatu populasi.

\section{BAHAN DAN METODE}

Bahan penelitian berupa isolat jamur Ganoderma philippii yang berasal dari isolasi sampel akar Acacia mangium di lapangan yang menunjukkan gejala penyakit busuk akar. Sampel akar diisolasi pada media Malt Extract Agar (MEA) 1\% (10g/L) dengan penambahan antibiotik 50 ppm Penicillin, 50 ppm Streptomycin, 25 ppm Polymyxcin, dan 230 ppm Thiabendazole dalam bentuk agar miring. Sampel akar diambil dari dua lokasi blok pengamatan permanen yang berbeda umur rotasi yaitu Logas (Riau) dengan umur rotasi pertama dan Deras (Sumatera Selatan) dengan umur rotasi kedua.

Isolat jamur yang digunakan untuk tes somatik inkompatibilitas disubkultur dari koleksi kultur yang disimpan dalam bentuk agar miring dengan mineral oil. Isolat ini menunjukkan tanda-tanda jamur Ganoderma philippii secara morfologi dan sudah diverifikasi dengan penanda DNA. Isolat jamur disubkultur pada media Potato Dextrose Agar (PDA) 39g/L dalam cawan Petri (diameter $90 \mathrm{~mm}$ ) sebagai initial plate. Hasil subkultur diinkubasi selama 2 minggu untuk pertumbuhan miselium yang maksimal pada suhu $25^{\circ} \mathrm{C}$ dalam ruang inkubasi. Tujuan pembuatan initial plate ini agar isolat jamur mempunyai umur yang seragam dan pertumbuhan yang seragam dalam hal meristematis, viabilitas dan vigoritas.

Prosedur pengujian dimulai dari memasangkan dua isolat jamur $G$. philippii untuk menge- 
tahui keragaman genetik dilakukan pada media Potato Dextrose Agar (PDA) 39g/L dalam cawan Petri (diameter $90 \mathrm{~mm}$ ). Blok inokulum diambil dari initial plate dengan ukuran kira-kira $3 \mathrm{~mm}^{2}$ kemudian diletakkan dengan jarak kurang lebih 1-2 $\mathrm{mm}$ antar dua isolat (De Giola et al., 2003). Pembuatan blok inokulum diusahakan mempunyai ukuran yang sama antara satu dengan lainnya dalam setiap cawan Petri, agar mempunyai pertumbuhan yang seragam. Isolat induk (parents culture) juga dibuat dari initial plate untuk setiap isolat yang akan diuji, tujuannya sebagai referensi isolat dalam memberi skor uji pasangan. Semua kombinasi isolat yang diuji dan isolat induk dibuat dalam 3 ulangan. Kultur per- cobaan diinkubasi pada suhu $25^{\circ} \mathrm{C}$ dalam ruang inkubasi dan diamati setiap 2 hari sekali untuk mengetahui pertumbuhan dan kontaminasinya.

Isolat jamur $G$. philippii yang diuji dapat dilihat dalam Tabel 1. Semua isolat akan dipasangkan dengan kombinasi yang sama untuk setiap lokasi, yaitu dari isolat itu sendiri atau selfpairing maupun dari isolat lain dari pohon yang berbeda dalam satu lokasi. Kombinasi pasangan isolat jamur G. philippii dapat dilihat pada Tabel 2 dan Tabel 3.

Hasil dari uji pasangan ini dievaluasi setelah 2 minggu. Reaksi inkompatibilitas antar isolat dinilai berdasarkan tingkat pertentangannya dengan menggunakan metode Adaskaveg dan

Tabel 1. Kultur jamur Ganoderma philippii dari dua lokasi yang berbeda umur rotasi.

\begin{tabular}{|ll|lc|}
\hline \multicolumn{5}{|c|}{ Kultur jamur Ganoderma philippii } \\
\hline \multicolumn{2}{|c|}{ Lokasi Logas (Riau) rotasi pertama } & \multicolumn{1}{|c|}{ Lokasi Deras (Sumatera Sclatan) rotasi kedua } \\
\hline 6-LS-3-A-36(M).3 & LS-A & 4-D-2-A-42(M)-A.2.1 & D-A \\
6-LS-3-A-44(M).3 & LS-B & 4-D-2-A-63(M)-C.1.1 & D-B \\
6-LS-3-A-45(M).3 & LS-C & 4-D-2-A-64(M)-B.1.2.1 & D-C \\
6-LS-3-A-54(M).3 & LS-D & 5-D-3-A-48.1 & D-D \\
6-LS-3-A-55(M).2 & LS-E & 5-D-3-A-72.1 & D-E \\
6-LS-3-A-66(M).3 & LS-F & 8-ND-6-A-56(M)-A.1 & D-F \\
6-LS-3-A-76(M).3 & LS-G & 8-ND-6-A-68(M)-A.1 & D-G \\
6-LS-3-A-77(M).1 & LS-H & 8-ND-6-A-87(M)-A.1 & D-H \\
6-LS-3-A-78(M).3 & LS-I & 8-ND-6-A-90(M)-A.2 & D-I \\
\hline
\end{tabular}

Tabel 2. Pemasangan antar isolat jamur Ganoderma philippii pada lokasi Logas (Riau) rotasi pertama.

\begin{tabular}{|c|c|c|c|c|c|c|c|c|c|c|c|}
\hline & & & LS-A & LS-B & LS-C & LS-D & LS-E & LS-F & LS-G & LS-H & LS-1 \\
\hline Parent cultures & $\rightarrow$ & & 3 & 3 & 3 & 3 & 3 & 3 & 3 & 3 & 3 \\
\hline \multicolumn{12}{|c|}{ Comparison plates $\downarrow$} \\
\hline 6-LS-3-A-36(M).3 & & LS-A & 3 & 3 & 3 & 3 & 3 & 3 & 3 & 3 & 3 \\
\hline 6-LS-3-A-44(M).3 & & LS-B & & 3 & 3 & 3 & 3 & 3 & 3 & 3 & 3 \\
\hline 6-LS-3-A-45(M).3 & & LS-C & & & 3 & 3 & 3 & 3 & 3 & 3 & 3 \\
\hline 6-LS-3-A-54(M). 3 & & LS-D & & & & 3 & 3 & 3 & 3 & 3 & 3 \\
\hline 6-LS-3-A-55(M). 2 & & LS-E & & & & & 3 & 3 & 3 & 3 & 3 \\
\hline 6-LS-3-A-66(M).3 & & LS-F & & & & & & 3 & 3 & 3 & 3 \\
\hline 6-LS-3-A-76(M).3 & & LS-G & & & & & & & 3 & 3 & 3 \\
\hline 6-LS-3-A-77(M).1 & & LS-H & & & & & & & & 3 & 3 \\
\hline 6-LS-3-A-78(M). 3 & & LS-I & & & & & & & & & 3 \\
\hline
\end{tabular}


Tabel 3. Pemasangan antar isolat jamur Ganoderma philippii pada lokasi Deras (Sumatera Selatan) rotasi kedua.

\begin{tabular}{|c|c|c|c|c|c|c|c|c|c|c|c|}
\hline & & & D-A & D-B & D-C & D-D & D-E & D-F & D-G & D-H & D-I \\
\hline Parent cultures & $\rightarrow$ & & 3 & 3 & 3 & 3 & 3 & 3 & 3 & 3 & 3 \\
\hline Comparison plates & $\downarrow$ & & & & & & & & & & \\
\hline 4-D-2-A-42(M)-A.2.1 & & D-A & 3 & 3 & 3 & 3 & 3 & 3 & 3 & 3 & 3 \\
\hline 4-D-2-A-63(M)-C.1.1 & & D-B & & 3 & 3 & 3 & 3 & 3 & 3 & 3 & 3 \\
\hline 4-D-2-A-64(M)-B.1.2.1 & & D-C & & & 3 & 3 & 3 & 3 & 3 & 3 & 3 \\
\hline $5-\mathrm{D}-3-\mathrm{A}-48.1$ & & D-D & & & & 3 & 3 & 3 & 3 & 3 & 3 \\
\hline 5-D-3-A-72.1 & & D-E & & & & & 3 & 3 & 3 & 3 & 3 \\
\hline 8-ND-6-A-56(M)-A.1 & & D-F & & & & & & 3 & 3 & 3 & 3 \\
\hline 8-ND-6-A-68(M)-A.1 & & D-G & & & & & & & 3 & 3 & 3 \\
\hline 8-ND-6-A-87(M)-A.1 & & D-H & & & & & & & & 3 & 3 \\
\hline 8-ND-6-A-90(M)-A.2 & & D-I & & & & & & & & & 3 \\
\hline & & & & & & & & & & & \\
\hline
\end{tabular}

Gilbertson (1987) dalam Latiffah dan Ho (2005) yang telah dimodifikasi. Metode ini menggunakan angka 0-2 sebagai nilai derajat pertentangan antar isolat, yaitu $0=$ kompatibel (tidak terjadi reaksi), 1 = inkompatibel tanpa pigmentasi (terjadi reaksi tanpa pembentukan garis pigmentasi), 2 = inkompatibel dengan pigmentasi (terjadi reaksi dengan pembentukan garis pigmentasi).

\section{HASIL DAN PEMBAHASAN}

\section{a. Uji somatik inkompatibilitas}

Hasil dari uji pasangan dua isolat G. philippii baik secara self-pairing atau dengan isolat yang berbeda pohon menunjukkan reaksi yang berbeda untuk setiap lokasi. Reaksi pemasangan antar dua isolat G. philippii dapat dilihat pada Tabel 4 dan Tabel 5. Reaksi kompatibel atau tidak adanya keragaman genetik dalam satu lokasi ditemukan pada uji pasangan isolat dari lokasi Logas (Riau) rotasi pertama. Pemasangan isolat G. philippii tidak membentuk garis pemisah di antara kedua miselium. Semua isolat tumbuh bersama dan menyatu dengan isolat yang lain membentuk koloni tunggal (Gambar 1). Miselia jamur saling bergabung dan hifa mengalami anastomosis yaitu penggabungan dua hifa yang berbeda menjadi hifa dikaryotik yang diikuti dengan perpindahan isi hifa. Anastomosis pada hifa biasanya diikuti dengan terbentuknya struktur septal khusus pada miselia jamur yang disebut dengan clamp connection yang merupakan ciri khas pada jamur golongan Basidiomycetes (Gambar 2) (Worall, 2010). Somatik kompatibilitas yang terjadi pada lokasi Logas merupakan penggabungan dua miselium sekunder (dikaryotik) isolat jamur $G$. philippii yang mempunyai hubungan yang dekat atau berasal dari klon yang sama (Worall, 1997). Tidak adanya keragaman genetik dalam populasi G. philippii lokasi Logas mengindikasikan bahwa secara genetik $G$. philippii Logas berasal dari satu klon yang identik (Suwandi et al., 2004). Semua isolat yang digunakan untuk uji pasangan berasal dari akar yang terinfeksi jamur $G$. philippii yang secara somatik mempunyai kecocokan yang sama satu dengan lainnya sehingga dapat dikelompokkan dalam satu kelompok SIG (Somatic Incompatibility Group).

Fenomena ini tidak hanya terjadi pada selfpairing tetapi juga pada kombinasi pasangan 
dengan isolat yang lainnya yang berasal dari pohon yang berbeda dalam satu lokasi.

Reaksi kompatibel juga ditemukan pada beberapa uji pasangan pada lokasi Deras (Sumatera Selatan). Tidak hanya pada uji pasangan self-pairing tapi juga pada beberapa kombinasi pasangan dengan pohon yang berbeda seperti $\mathrm{D}(\mathrm{AxB}), \mathrm{D}(\mathrm{AxC}), \mathrm{D}(\mathrm{AxD}), \mathrm{D}(\mathrm{AxE})$, $D(A x G), D(A x H), D(A x I), D(B x C), D(B x E)$, $\mathrm{D}(\mathrm{BxG}), \mathrm{D}(\mathrm{BxH}), \mathrm{D}(\mathrm{BxI}), \mathrm{D}(\mathrm{CxE}), \mathrm{D}(\mathrm{CxG})$, $\mathrm{D}(\mathrm{CxH}), \mathrm{D}(\mathrm{CxI}), \mathrm{D}(\mathrm{ExG}), \mathrm{D}(\mathrm{ExH}), \mathrm{D}(\mathrm{ExI})$, $\mathrm{D}(\mathrm{GxI}), \mathrm{D}(\mathrm{HxI})$.

Reaksi inkompatibilitas (reaksi ketidakcocokan somatik) ditemukan pada beberapa uji pasangan isolat lokasi Deras (Sumatera Selatan) rotasi kedua. Reaksi ditunjukkan dalam berbagai macam fenomena bentuk demarkasi, mulai dari fenomena pembentukan zona jarang antar miselium jamur yang dipasangkan (Gambar 4), adanya garis seperti bendungan yang merupakan dinding sclerotia dari penggumpalan hifa yang terbentuk pada pertemuan dua miselium jamur (Gambar 3), atau pembentukan garis demarkasi yang disertai pembentukan pigmentasi (El Karkouri et al., 1996; Suwandi et al., 2004;
Guler, 2008). Bentuk garis demarkasi terbentuk pada hampir semua pasangan isolat yang mempunyai tipe miselia yang berbeda atau tidak identik secara genetik baik pada monosporous atau miselia sekunder (Worall, 1997). Reaksi ini kadang juga disertai dengan adanya pembentukan pigmentasi pada pertemuan miselium. Guler (2008) menjelaskan bahwa pembentukan pigmen di antara miselium jamur yang dipasangkan pada uji inkompatibilitas itu merupakan hal yang penting. Pertemuan miselium jamur yang mem-

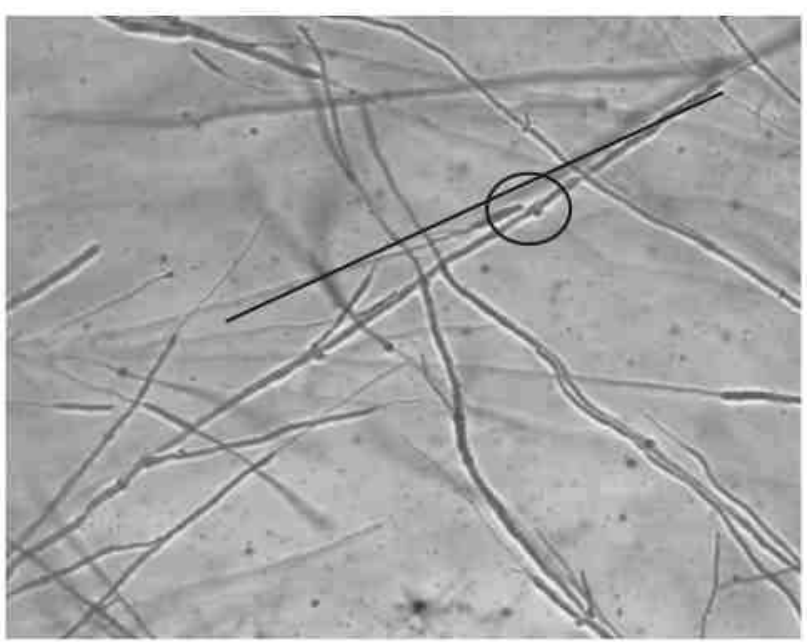

Gambar 2. Anastomosis antara dua miselia dari dua isolat yang dipasangkan pada reaksi kompatibel (garis lurus) dengan diikutil pembentukan clamp connection (lingkaran) (bar: $20 \mu \mathrm{m})$.
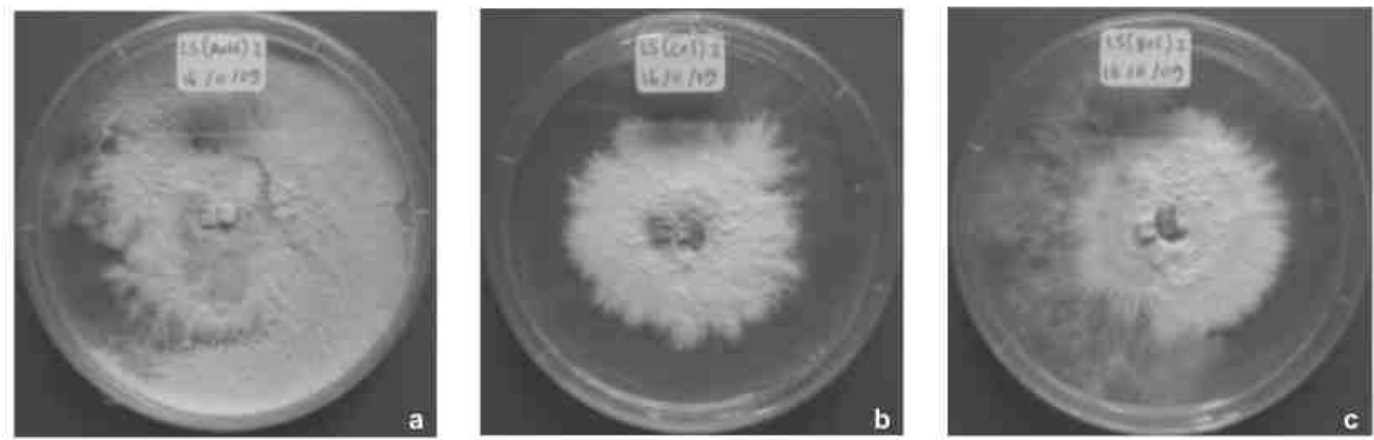

Gambar 1. Koloni tunggal yang terbentuk pada reaksi kompatibel antar isolat pada berbagai macam uji pasangan pada lokasi Logas (Riau). (a-b) Pertumbuhan menyatu miselium identik yang mempunyai kenampakan morfologi yang sama antar isolat pada uji pasangan LS(AxH) dan uji pasangan LS(CxI), Koloni tunggal dari miselium dengan kenampakan morfologi yang sedikit berbeda tetapi identik secara genetik pada uji pasangan $\operatorname{LS}(\mathrm{BxC})$. 
bentuk demarkasi baik yang berbentuk dinding sclerotia atau zona jarang sangat sulit untuk dilihat dengan mata telanjang. Perlu hati-hati dalam mengamati bentuk pertemuan miselium, hal ini dapat dibantu dengan pigmentasi yang terbentuk pada pertemuan antar miselium jamur. Terbentuknya pigmentasi sangat membantu dalam menentukan inkompatibilitas suatu uji pasangan. Akan tetapi tidak semua reaksi inkompatibel membentuk pigmentasi pada pertemuan miseliumnya, seperti hasil yang dipaparkan oleh Suwandi et al. (2004) pada Rigidoporus lignosus menunjukkan dua tipe inkompatibilitas, yaitu adanya zona demarkasi miselium yang jarang tanpa adanya pigmentasi dan zona demarkasi miselium dengan pembentukan pigmentasi. Perbedaan pigmentasi ini dipengaruhi oleh faktor media kultur yang dapat mempengaruhi intensitas reaksi inkompatibilitas.

Hasil reaksi inkompatibilitas lokasi Deras (Sumatera Selatan) menunjukkan adanya perbedaan pembentukan pigmentasi, yaitu 6 reaksi inkompatibilitas pada uji pasangan $\mathrm{D}(\mathrm{BxD})$, $\mathrm{D}(\mathrm{CxD}), \mathrm{D}(\mathrm{DxH}), \mathrm{D}(\mathrm{FxH}), \mathrm{D}(\mathrm{FxI})$, dan $\mathrm{D}(\mathrm{GxH})$ yang tidak membentuk pigmentasi pada pertemuan miseliumnya. Sedangkan untuk semua kombinasi pengujian dengan isolat Deras (F) dan beberapa kombinasi pengujian dengan isolat Deras (D) membentuk pigmentasi pada pertemuan miseliumnya. Pigmentasi mulai dapat dilihat pada umur 2 minggu yang ditandai dengan adanya garis berwarna kuning kecoklatan pada pertemuan miselium jamur yang berubah menjadi coklat oranye kemerahan pada umur lanjut (Gambar 5). Perlu hati-hati dalam menentukan pigmentasi pada isolat jamur jenis Ganoderma, karena isolat jamur Ganoderma akan membentuk crustose pada perkembangan lanjut, sehingga menyebabkan kerancuan dalam melihat pigmentasi. Pigmentasi dari reaksi inkompatibilitas terlihat pada awal pertumbuhan miselium dan pada awal pertemuan miselium, berbeda halnya dengan crustose atau penggumpalan miselium yang akan terbentuk setelah isolat berumur tua.

Anastomosis tidak akan terjadi pada pertemuan dua miselium sekunder (miselium dikaryotik) dari dua isolat jamur yang tidak mempunyai hubungan yang dekat atau tidak identik secara genetik. Anastomosis gagal dan tidak akan terjadi perubahan atau perpindahan nuklei (genetik) dari miselium sekunder satu ke miselium sekunder lainnya (Gambar 6). Pada reaksi inkompatibel, hifa membawa nuklei yang berbeda satu dengan lainnya dan tidak identik secara genetik yang akan membentuk koloni yang heterokaryotik (Guler, 2008). Berbeda halnya pada reaksi kompatibel, terjadi proses anastomosis yang disertai dengan perubahan atau perpindahan nuklei (genetik) yang tidak menye-

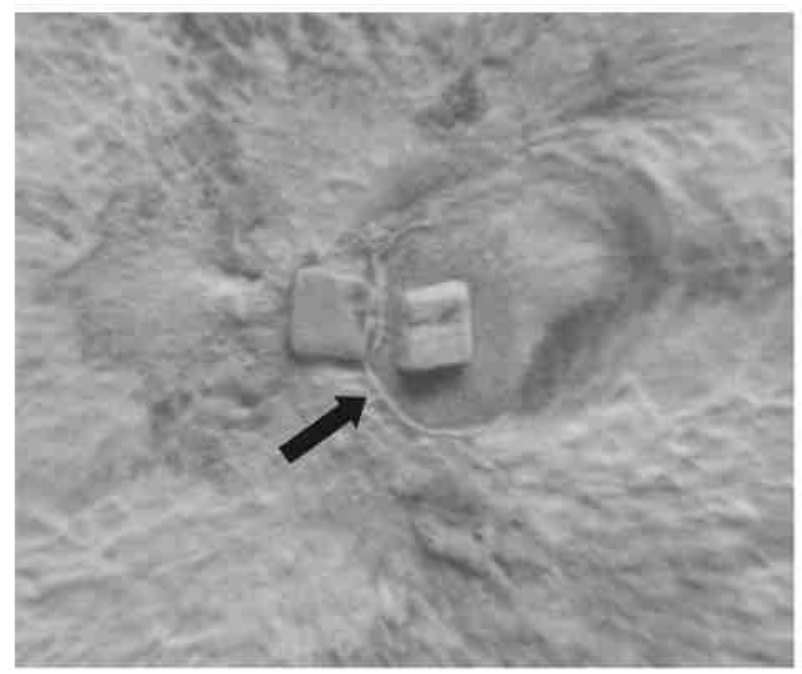

Gambar 3. Pembentukan zona bendungan yang berupa dinding sclerotia (anak panah) yang merupakan hasil reaksi inkompatibel dari pertemuan dua isolat yang berbeda klon genetik pada Deras $(\mathrm{AxF})$. 
babkan berubahnya klon genetik karena masih berasal dari satu klon yang sama.

Dari Tabel 4 dan Tabel 5 dapat diketahui bahwa pada lokasi Deras rotasi kedua lebih mempunyai variasi atau keragaman genetik dalam satu spesies jika dibandingkan dengan lokasi Logas rotasi pertama. Populasi jamur $G$. philippii lokasi Logas dapat dikelompokkan dalam satu somatic incompatibility group (SIGLogas), sedangkan pada lokasi Deras populasi
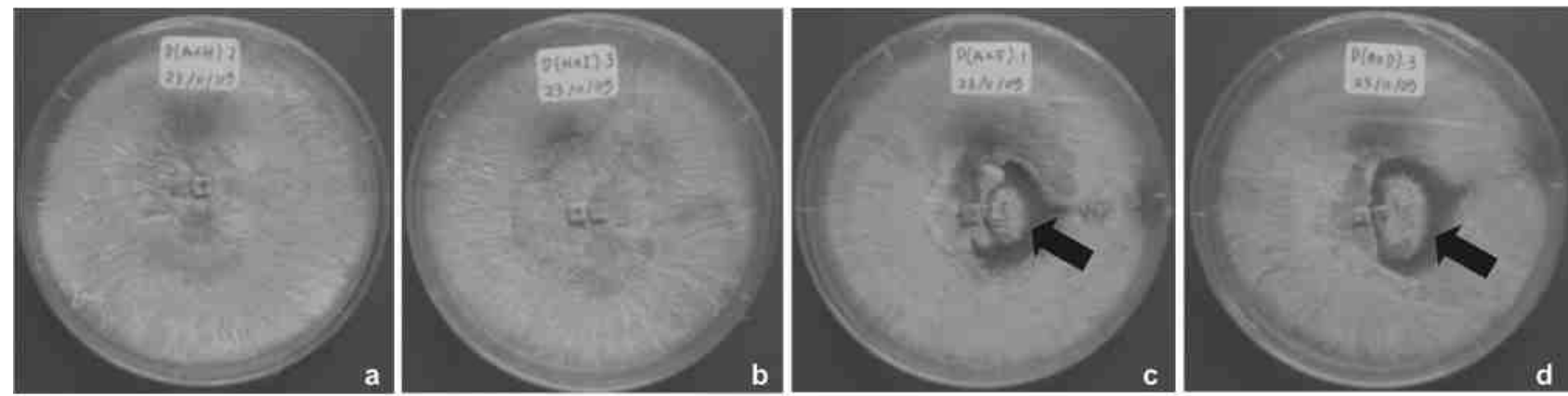

Gambar 4. Hasil reaksi pasangan isolat pada lokasi Deras (Sumatera Selatan). Koloni tunggal yang terbentuk dari bergabungnya miselium jamur yang identik secara genetik sebagai hasil reaksi kompatibel pada berbagai uji pasangan, tidak hanya pada self-pairing $(\mathrm{a}-\mathrm{b})$, reaksi inkompatibel dengan pembentukan zona jarang antar miselium yang tidak sama secara genetik (anak panah) pada uji pasangan $\mathrm{D}(\mathrm{AxF})$ dan $\mathrm{D}(\mathrm{BxD})(\mathrm{c}-\mathrm{d})$.
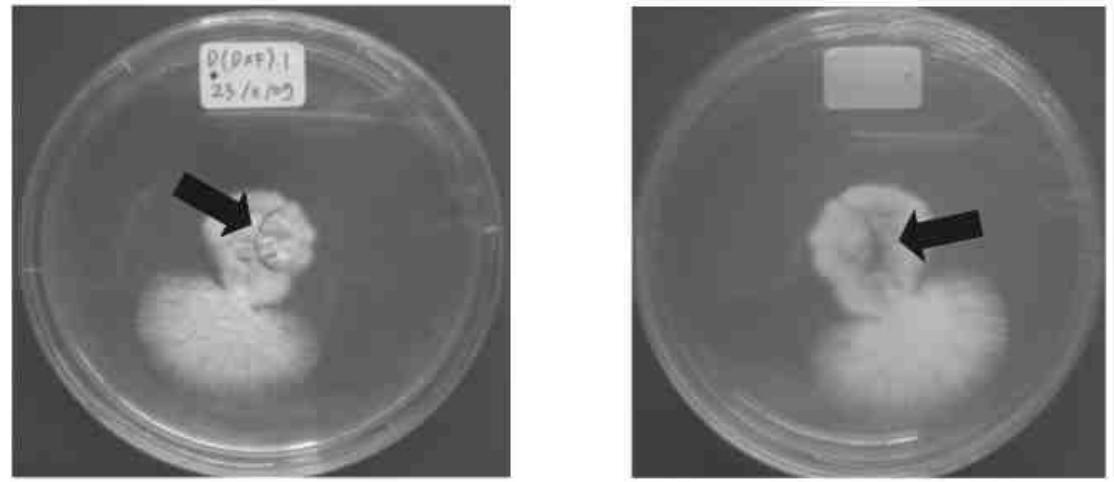

Gambar 5. Pembentukan pigmentasi berwarna coklat oranye kemerahan (anak panah) pada zona garis demarkasi yang merupakan pertemuan antar dua isolat yang inkompatibel pada uji pasangan $\mathrm{D}(\mathrm{DxF})$ pada lokasi Deras (Sumatera Selatan). (a) Tampak atas, (b) Tampak bawah.

Tabel 4. Hasil somatik inkompatibilitas antar isolat jamur Ganoderma philippii pada lokasi Logas (Riau).

\begin{tabular}{lllllllllll}
\hline Comparison plates & & LS-A & LS-B & LS-C & LS-D & LS-E & LS-F & LS-G & LS-H & LS-I \\
\hline 6-LS-3-A-36(M).3 & LS-A & 0 & 0 & 0 & 0 & 0 & 0 & 0 & 0 & 0 \\
6-LS-3-A-44(M).3 & LS-B & & 0 & 0 & 0 & 0 & 0 & 0 & 0 & 0 \\
6-LS-3-A-45(M).3 & LS-C & & & 0 & 0 & 0 & 0 & 0 & 0 & 0 \\
6-LS-3-A-54(M).3 & LS-D & & & & 0 & 0 & 0 & 0 & 0 & 0 \\
6-LS-3-A-55(M).2 & LS-E & & & & & 0 & 0 & 0 & 0 & 0 \\
6-LS-3-A-66(M).3 & LS-F & & & & & & 0 & 0 & 0 & 0 \\
6-LS-3-A-76(M).3 & LS-G & & & & & & & 0 & 0 & 0 \\
6-LS-3-A-77(M).1 & LS-H & & & & & & & & 0 & 0 \\
6-LS-3-A-78(M).3 & LS-I & & & & & & & & & 0 \\
\hline
\end{tabular}

Ket. : $0=$ kompatibel, $1=$ inkompatibel tanpa pigmentasi, $2=$ inkompatibel dengan pigmentasi 
Tabel 5. Hasil somatik inkompatibilitas antar isolat jamur Ganoderma philippii pada lokasi Deras (Sumatera Selatan).

\begin{tabular}{llllllllllll}
\hline Comparison plates & & D-A & D-B & D-C & D-D & D-E & D-F & D-G & D-H & D-I \\
\hline 4-D-2-A-42(M)-A.2.1 & D-A & 0 & 0 & 0 & 0 & 0 & 2 & 0 & 0 & 0 \\
4-D-2-A-63(M)-C.1.1 & D-B & 0 & 0 & 1 & 0 & 2 & 0 & 0 & 0 \\
4-D-2-A-64(M)-B.1.2.1 & D-C & & & 0 & 1 & 0 & 2 & 0 & 0 & 0 \\
5-D-3-A-48.1 & D-D & & & 0 & 2 & 2 & 2 & 1 & 2 \\
5-D-3-A-72.1 & D-E & & & & 0 & 2 & 0 & 0 & 0 \\
8-ND-6-A-56(M)-A.1 & D-F & & & & & 0 & 2 & 1 & 1 \\
8-ND-6-A-68(M)-A.1 & D-G & & & & & & 0 & 1 & 0 \\
8-ND-6-A-87(M)-A.1 & D-H & & & & & & & 0 & 0 \\
8-ND-6-A-90(M)-A.2 & D-I & & & & & & & & 0 \\
\hline
\end{tabular}

Ket. : $0=$ kompatibel, 1 = inkompatibel tanpa pigmentasi, 2 = inkompatibel dengan pigmentasi

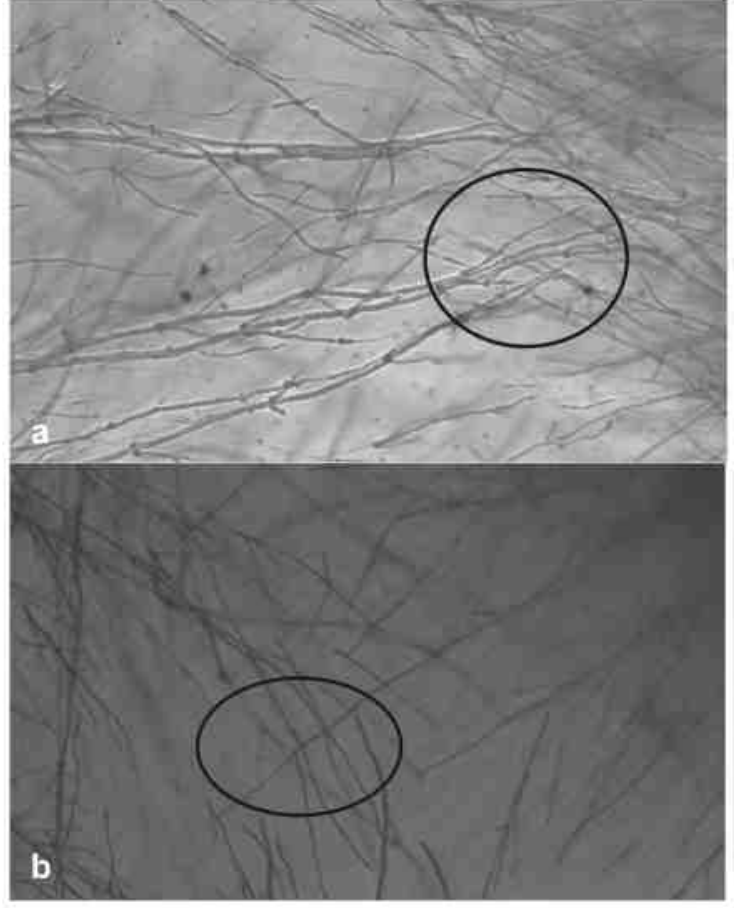

Gambar 6. Kenampakan reaksi kompatibel dan reaksi inkompatibel pada lokasi Deras di bawah mikroskop dengan perbesaran $20 \mu \mathrm{m}$. (a) Anastomosis antara dua hifa (lingkaran) yang identik pada uji pasangan $\mathrm{D}(\mathrm{AxG})$ pada reaksi kompatibel. (b) Anastomosis tidak terjadi, hifa saling bertumpang tindih (lingkaran) pada uji pasangan $\mathrm{D}(\mathrm{AxF})$ pada reaksi inkompatibel.

jamur G. philippii dapat dikelompokkan dalam tiga somatic incompatibility group, yaitu SIG-

Deras1: semua kombinasi dengan Deras (D), SIG-Deras2: semua kombinasi dengan Deras (F), dan SIG-Deras3: untuk semua kombinasi yang menunjukkan reaksi kompatibel. Kedua isolat (Deras (D) dan Deras (F)) menunjukkan reaksi inkompatibilitas yang mengindikasikan adanya keragaman genetik dalam suatu individu/populasi jika dikombinasikan dengan isolat jamur yang lain (kolom hijau). Sedangkan untuk isolat jamur yang lain, tidak menunjukkan adanya keragaman genetik dari hasil uji pasangannya, kecuali untuk uji pasangan $\mathrm{D}(\mathrm{GxH})$ yang menunjukkan adanya keragaman (kolom oranye) dan uji pasangan $\mathrm{D}(\mathrm{AxD})$ yang tidak menunjukkan adanya keragaman (kolom oranye). Uji $\mathrm{D}(\mathrm{AxD})$ seharusnya menunjukkan reaksi inkompatibel karena semua isolat Deras(D) tidak identik secara genetik jika dipasangkan dengan isolat yang lain. Jika isolat Deras (A) menunjukkan reaksi kompatibel dengan isolat Deras(D) asumsinya semua isolat juga akan menunjukkan reaksi yang sama, tidak ada keragaman, karena isolat Deras(A) identik secara genetik dengan isolat yang lain, begitu sebaliknya untuk uji pasangan $\mathrm{D}(\mathrm{GxH})$. Pengecualian ini dapat saja terjadi karena adanya interaksi elemen-elemen seperti $\mathrm{K}, \mathrm{P}, \mathrm{Cu}, \mathrm{Fe}, \mathrm{Ca}, \mathrm{C}, \mathrm{O}$, $\mathrm{Mg}, \mathrm{Al}, \mathrm{Zn}, \mathrm{Se}, \mathrm{Mo}, \mathrm{Cd}$ dalam hifa setiap isolat yang menyebabkan perubahan struktur atau kadar elemen dalam hifa. Seperti halnya studi 
tentang somatik inkompatibilitas pada Agaricus bitorquis yang dilakukan oleh Guler (2008) yang menjelaskan bahwa semua komponen elemen tersebut berperan sama dalam siklus nutrisi pada Agaricus.

\section{b. Model Persebaran Penyakit Busuk Akar}

Studi tentang somatik inkompatibilitas dapat digunakan untuk mengetahui model persebaran jamur. Proses perbedaan reproduksi dalam populasi Basidiomycetes ( $G$. philippii) dapat diasumsikan sebagai dasar penting dalam distribusi dikaryons (Pilotti et al., 2003). Dari hasil studi somatik inkompatibilitas menunjukkan bahwa dua lokasi yang berbeda umur rotasi mempunyai tipe keragaman genetik yang berbeda. Lokasi Logas (Riau) dengan umur rotasi pertama menunjukkan tidak adanya keragaman genetik dalam jamur G. philippii. Penyakit busuk akar merah yang disebabkan oleh jamur G. philippii berasal dari satu klon yang sama. Hal ini mengindikasikan bahwa persebaran penyakit akar terjadi melalui kontak dari akar ke akar antar pohon yang berdekatan. Tidak ditemukan adanya spora dari klon lain yang menempel pada tunggak kayu yang tersisa. Hal ini bisa terjadi karena Logas merupakan areal pertanaman rotasi pertama yang berasal dari konversi hutan alam yang notabene bukan tanaman monokultur. Jadi timbulnya penyakit tidak secara epidemik. Rotasi pertama berarti belum terjadi pemanenan dari hasil penanaman monokultur, sehingga tidak ada sisa-sisa tunggak kayu yang sejenis yang rentan terhadap penyakit busuk akar yang tertinggal di dalam tanah. Akan tetapi perlu dipahami pula bahwa ada kemungkinan terjadi keragaman individu jamur Ganoderma dalam suatu hutan alam karena akibat persebaran basidiospora dari tubuh buah yang tidak identik yang terbentuk pada tunggak-tunggak kayu, sehingga rotasi pertama tidak selalu dapat dijadikan pedoman bahwa tidak akan terjadi keragaman genetik dalam populasi jamur Ganoderma.

Sedangkan pada lokasi Deras (Sumatera Selatan) yang merupakan rotasi kedua ditemukan adanya keragaman genetik. Keragaman genetik dalam satu spesies ini terjadi karena adanya persebaran basidiospora yang berasal dari tubuh buah yang terbentuk pada tunggak bekas rotasi pertama. Perlu diingat bahwa patogen dapat menyerang secara epidemik pada tanaman monokultur, sehingga masih tersimpan sisa-sisa tunggak kayu dengan penyakit busuk akar dari rotasi sebelumnya sebagai sumber inokulum. Miselium jamur akan membentuk tubuh buah yang menghasilkan basidiospora jika menemukan substrat yang tepat, sehingga tubuh buah akan terbentuk pada tunggak-tunggak kayu yang tertinggal dalam areal tanaman. Spora akan menempel dan membentuk koloni miselium pada sisa tunggak kayu yang ada dan akan menular ke pohon yang lain melalui kontak akar (Gambar 7).

Satu hal yang perlu dipahami tentang penyakit busuk akar oleh jamur Ganoderma adalah bahwa kejadian busuk akar dan keragaman genetik akan meningkat seiring dengan bertambahnya umur rotasi.

Pemahaman tentang pola atau model persebaran penyakit busuk akar dapat digunakan untuk menentukan cara pengendalian penyakit. Pola persebaran penyakit melalui persebaran spora dapat dikendalian dengan cara membersihkan tunggak-tunggak yang tersisa di dalam areal pertanaman, sehingga tidak akan ada substrat 
yang tepat bagi jamur sebagai tempat berkembang biak. Penyulaman dan pembersihan tanaman yang terserang penyakit busuk akar dilakukan untuk menghindari terjadinya kontak akar antar akar tanaman sehat dengan akar tanaman yang terserang, sehingga dapat menekan persebaran penyakit dalam satu areal pertanaman. Namun demikian, cara penyulaman dan pembersihan di HTI Acacia akan sulit dan mahal dilakukan bila pertanaman sudah berumur lebih dari tiga bulan atau bila kanopi sudah mulai saling bersentuhan.

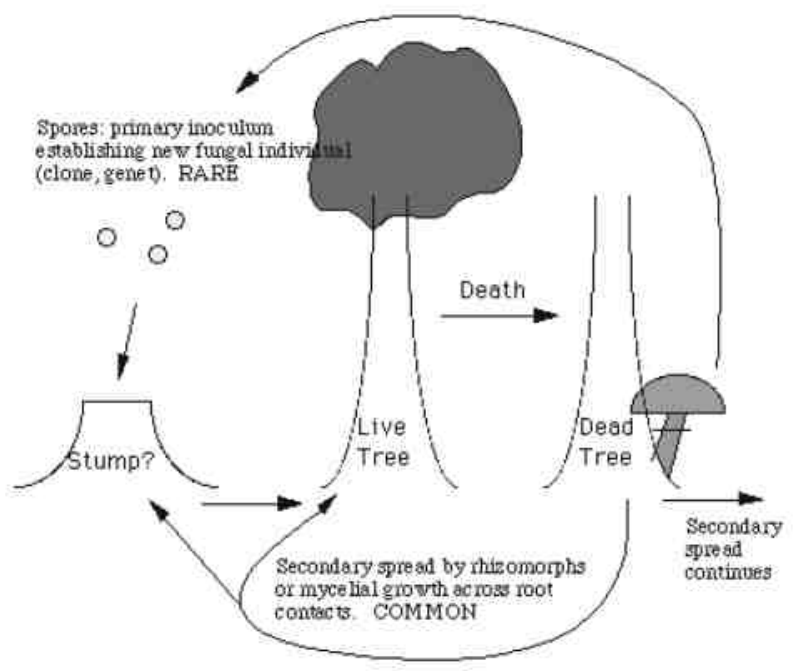

Gambar 7. Pola persebaran jamur root rot melalui kontak akar (A) maupun melalui persebaran spora (B) (Worall, 2010).

Keragaman genetik yang diketahui pada suatu lokasi dapat dijadikan acuan dalam pengendalian. Lokasi dengan keragaman populasi yang tinggi akan lebih sulit untuk dikendalikan karena setiap individu yang berbeda mempunyai respon yang berbeda-beda. Hal ini diasumsikan jika kita ingin menerapkan antagonis alami (bio-control) pada suatu areal dengan keragaman jamur Ganoderma yang tinggi, maka diperlukan perlakuan yang berbeda, tidak bisa disamakan.
Berbeda halnya jika tidak ditemukan adanya keragaman genetik dalam suatu populasi, maka pengendalian dapat dilakukan dengan seragam dan lebih mudah.

\section{KESIMPULAN}

Jamur Ganoderma philippii penyebab penyakit busuk akar pada tanaman Acacia mangium berasal dari klon yang sama dan identik secara genetik untuk lokasi Logas rotasi pertama, sedangkan di lokasi Deras rotasi kedua mempunyai keragaman genetik yang berbeda dan tidak berasal dari satu klon yang sama. Hasil uji inkompatibilitas somatik ini menunjukkan bahwa penyebaran penyakit busuk akar dapat terjadi melalui kontak akar (seperti terjadi pada tanaman rotasi pertama di Logas Riau) dan gabungan antara kontak akar dan penyebaran spora (seperti terjadi pada tanaman rotasi kedua di Deras Sumatera Selatan).

\section{UCAPAN TERIMA KASIH}

Penelitian ini merupakan bagian dari proyek kerjasama penelitian antara Balai Besar Penelitian Bioteknologi dan Pemuliaan Tanaman Hutan dengan Universitas Tasmania Australia dan CSIRO, dengan tema "Management of Rootrot in Acacia Plantation in Indonesia". Proyek penelitian ini didukung dana dari ACIAR. Penulis mengucapkan terima kasih kepada semua pihak yang telah membantu kelancaran penelitian ini, khususnya kepada mitra kerja proyek ini yakni PT. MHP, PT. Arara Abadi dan PT. RAPP. Penulis juga mengucapkan terima kasih kepada Caroline L. Mohammed dan Anthony Francis. 


\section{DAFTAR PUSTAKA}

De Giola, T., Ubaldo, R., Sicoli, G., and Luisi, N. 2003. Occurrence and distribution of Armillaria gallica genets in a declining oak stand of southern Italy. Phytopathol. Mediterr. 42: 199-204.

El Karkouri, K., Cleyet-Marel, J.-C., Mousain, D. 1996. Isozyme variation and somatic incompatibility in population of the ectomycorrizhal fungus Suillus collinitus. New Phytol. 134: 143-153.

Fries, N. 1987. Somatic incompatibility and field distribution of the ectomycorrhizal fungus Suillus luteus (Boletaceae). New Phytol. 107: 735-739.

Glen, M., Potter, K., Sulistyawati, P., Rimbawanto, A. 2006. Molecular identification of organisms associated with root and heart rot in Acacia mangium. In 'ACIAR Proceedings No. 124. Heart rot and root rot in tropical Acacia plantations: a synthesis of research progress, 7-9 February, Yogyakarta, Indonesia'. (Eds K Potter, A Rimbawanto, C Beadle). 55-59p.

Glen, M., Bougher, N.L., Francis, A., Nigg, S.Q., Lee, S.S., Irianto, R.S.B., Barry, K.M., Beadle, C.L., Mohammed, C.L. 2009. Ganoderma and Amauroderma species associated with root-rot disease of Acacia mangium plantation trees in Indonesia and Malaysia. Australian Plant Pathology. 38: 345-356.

Golani, G.D. 2006. Hardwood plantation development and threats to its sustainability in Indonesia. In 'ACIAR Proceedings No. 124. Heart rot and root rot in tropical Acacia plantations: a synthesis of research progress, 7-9 February, Yogyakarta, Indonesia'. (Eds K Potter, A Rimbawanto, C Beadle). 16-21p. Guler, P. 2008. Somatic incompatibility in Agaricus bitorquis (Quel.) Sacc.. African Journal of Biotechnologhy Vol. 7(3): 276281.

Hood, I.A. 2006. The mycology of the Basidiomycetes. In 'ACIAR Proceedings No. 124. Heart rot and root rot in tropical Acacia plantations: a synthesis of research progress, 7-9 February, Yogyakarta, Indonesia'. (Eds K Potter, A Rimbawanto, C Beadle).

Irianto, R.S.B., Barry, K.M., Hidayati, N., Ito, S., Fiani, A., Rimbawanto, A., Mohammed, C.L. 2006. Incidence, spatial analysis and genetic trial of root rot of Acacia mangium in Indonesia. Journal of Tropical Forest Science. 18: 157-165.

Latifah, Z. dan Ho, Y. W. 2005. Morphological Characteristics and Somatic Incompatibility of Ganoderma from Infected Oil Palm from Three Inland Estates. Malaysian Journal of Microbiology, Vol 1(2): 46-52.

Latiffah, Z., N.S. Ali, B. Shalleh, M. Zakaria. 2009. Molecular analysis of Ganoderma species from different hosts in Peninsula Malaysia. Journal of Biological Sciences. 9: 12-20.

Lee, S.S. 2000. The current status of root diseases of Acacia mangium Wild. In 'Ganoderma disease of perennial crops'. (Eds J Flood, PD Bridge, $\mathrm{M}$ Holderness) 71-79p. (CABI Publishing: Wallingford, UK).

Miller, R.N.G., Holderness, M., Bridge, P.D., Chung, G.F., Zakaria, M.H. 1999. Genetic 
diversity of Ganoderma in oil palm plantings. Plant Pathology. 48: 595-603.

Old, K., Lee, S.S., Sharma, J.K. and Yuan, Z.Q. 2000. A manual of diseases of tropical acacias in Australia, SE Asia and India. Bogor, Indonesia. Centre for International Forestry Research. 8p, 88-90p.

Pilotti, C.A., Sanderson, F.R., Aitken, E.A.B. 2003. Genetic structure of a population of Ganoderma boninense on oil palm. Plant Pathology. 52: 455-463.

Suwandi, Hamidson, H., Naito, S. 2004.

Distribution of Rigidoporus lignosus genotype in a rubber plantation, as revealed by somatic compatibility. Mycoscience. 45:72-75.

Worall, J.J. 1997. Somatic incompatibility in Basidiomycetes. Mycologia. 89(1): 24-36.

Worall, J.J. 2010. www.forestpathology.org. 